\title{
Timely sowing effect on incidence of aphid, Rhopalosiphum maidis in blond psyllium, Plantaga ovata, Forsk
}

\author{
RK Sanp \& V Singh
}

Journal of Agriculture and Ecology

ISSN: 2456-9410

Volume: 5

Journal of Agriculture and Ecology (2018) 5: 83-87 http://doi.org/10.53911/JAE.2018.5110

\section{and Ecology}

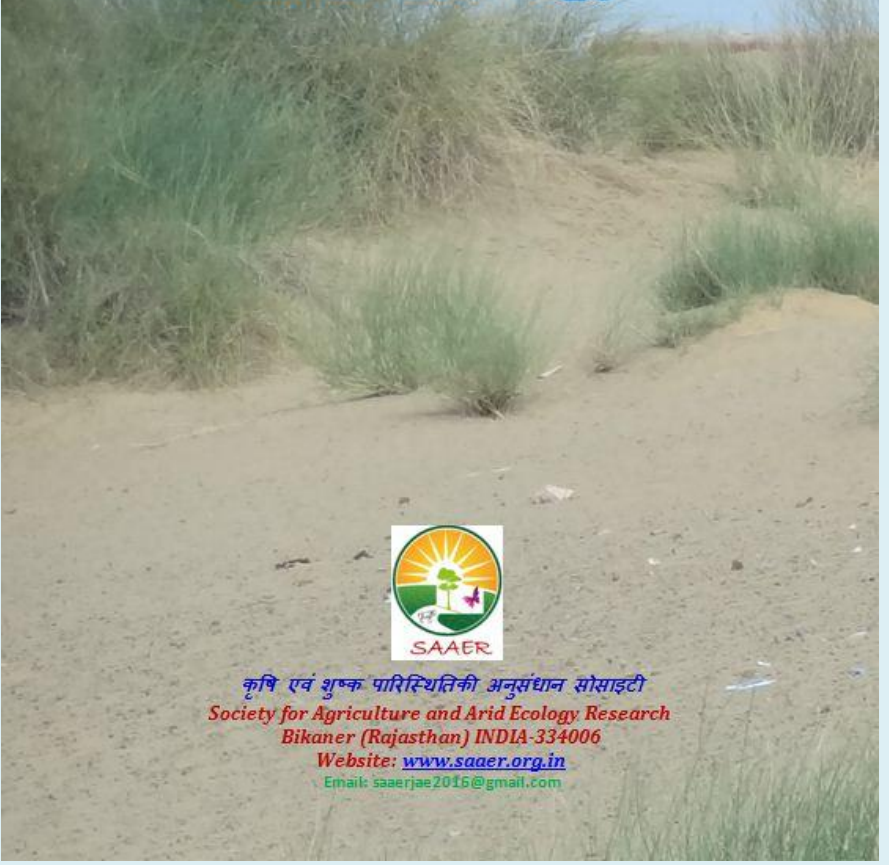




\title{
Timely sowing effect on incidence of aphid, Rhopalosiphum maidis in blond psyllium, Plantaga ovata, Forsk
}

\author{
RK Sanp ${ }^{1} \not \&$ V Singh \\ Department of Entomology, College of Agriculture, Swami Keshwanand Rajasthan Agricultural \\ University, Bikaner - 334006 (Rajasthan) \\ Corresponding author: RK Sanp, E-mail yadavrk.ento84@gmail.com
}

\begin{tabular}{|c|c|}
\hline Article Info & Abstract \\
\hline Art & To find out the effect of different \\
\hline & $\lg$ of \\
\hline & naidis \\
\hline & was dependent on the prevailed climatic conditions of the cropping seasons. \\
\hline August 2018 & The five different sowing dates revealed that early sown crop $\left(9^{\text {th }}\right.$ \\
\hline $\begin{array}{l}\text { Key Words: Sowing } \\
\text { time, blond psyllium, } R \text {. } \\
\text { maidis. }\end{array}$ & $\begin{array}{l}\text { highest seed yield }\left(7.32 \mathrm{q} \mathrm{ha}^{-1}\right) \text { was obtained as compared to the late sowing } \\
\text { crop } 30^{\text {th }} \text { December }(51.02 \text { aphids/tiller }) \text { whereas, minimum seed yield was } \\
\text { obtained on sown crop } 7^{\text {th }} \text { December }\left(4.03 \mathrm{q} \mathrm{ha}^{-1}\right) \text {. }\end{array}$ \\
\hline
\end{tabular}

Copyright (02018 Sanp \& Singh, This is an open access article published under the terms of the Creative Commons Attribution License, which permits unrestricted use, distribution, and reproduction in any medium, provided the original work is properly cited.

Preferred citation: Sanp RK \& Singh V. 2018. Timely sowing effect on incidence of aphid, Rhopalosiphum maidis in blond psyllium, Plantaga ovata, Forsk. Journal of Agriculture and Ecology, 5: 83-87; http://doi.org/10.53911/JAE.2018.5110.

\section{Introduction}

Isabgol is also known as blond psyllium, ispaghula, ispogel or Indian plantago. It belongs to the family Plantaginaceae with chromosome number $2 \mathrm{n}=8$. Isabgol is a plant of West Asian origin and was introduced in India during Muslim settlement in middle age. Isabgol is the first ranking export commodity among medicinal plants in India. India continues to rank first in its production and trade in the world market. Isabgol is a medicinal plant valued for its thin white husk on seed which is prescribed as a drug for certain ailments in Unani and Ayurvedic systems of medicine (Karnick 1976). It is used as laxative in traditional system of medicine, being beneficial in habitual constipation, chronic diarrhea, dysentery and irritation of digestive tract. It has the property of absorbing and retaining water (40-90\%) and therefore works as an anti-diarrhea drug. The low productivity of the crop is attributed due to the attack of insect pests and diseases. Among the insect pests exercising heavy toll of blond psyllium crop include aphids, Rhopalosi phummaidis (Fitch), Aphis gossypii Glov.; field cricket, Gryllus sp.; whitefly, Bemisia tabaci (Genn.) and field termites, Odonto termesobesus Rambur and Microtermesobesi Holmgren. Isabgol crop is attacked by number of insect pest, out of which aphid, Aphis gossypii Glover (Homoptera: Aphididae) has been reported as 
major pest of isabgol (Sagar \& Jindla 1984). The available literature indicated that not much work has been done on date of sowing specially in the arid-region of Rajasthan. Assessment of optimum sowing time has also been recognized as one of the main prerequisites for the establishment of effective integrated pest management programme which has been examined in the paper.

\section{Materials and methods}

An experiment was laid out in a simple randomized block design with five different dates of sowing viz., $9^{\text {th }}, 16^{\text {th }}, 23^{\text {rd }}, 30^{\text {th }}$, and $7^{\text {th }}$ each date replicated five times. The seeds of blond psyllium (variety RI-89) were sown in the plots measuring $3 \times 2 \mathrm{~m}^{2}$ at seven days intervals, starting from $9^{\text {th }}$ November to $7^{\text {th }}$ December, during both years rabi, 2013-14 and 2014-15. The row to row and plant to plant distance of $30 \mathrm{~cm}$ and $5 \mathrm{~cm}$ was maintained. The crop was allowed to have natural insect infestation. The observations on aphid population were recorded on five randomly selected tagged plants from each experimental plot soon after the appearance of aphid and then at weekly interval till harvesting the crop. Seed yield was also recorded after harvesting the crop. The per plot yield was converted into yield per hectare. The peak population of aphids recorded on different dates of sowing were transformed into $\log (\mathrm{X}+1)$ values. The correlation coefficient and regression equations of date of sowing with aphid and yield were worked out by subjecting the data to simple correlation coefficient (r) and liner regression analysis. Coefficient of determination (variance explained) was calculated by simple correlation coefficient.

\section{Results and discussion}

Over all mean of the observations during rabi, 2013-14 and 2014-15 the minimum aphid population was found on the crop sown on $09^{\text {th }}$ November (21.84 aphids/tiller) which was significantly superior over the rest dates of sowing. The maximum aphid population was recorded on the crops sown on $30^{\text {th }}$ November (51.02 aphids/tiller) followed by $07^{\text {th }}$ December (43.21 aphids/tiller) and these were at par to each other. Rest of the dates of sowing $16^{\text {th }}$ November and $23^{\text {rd }}$ November were observed in middle order with aphid population (28.38 and 37.85 aphids/tiller) respectively (Table $1 \&$ Figure 1 ). Trehan et al. (1970), Singh (1979), Singh (1982), Sharma (1990), Ram \& Pareek (1993), Marzouk \& Bawab (1999), Khinchi \& Kumawat (2014) and Jat et al. (2016) observed low population of aphid, R. maidis on early sown crop which corroborates with the present findings. The results of Patel \& Singh (2018) on mustard aphid L. erysimi also corroborate the present findings with lowest aphid infestation on early sown crop. 
Fig. 1 Effect of sowing dates on the incidence of Rhopalosiphum maidis of $P$. ovata during rabi, 2013-14 and 2014-15 (Pooled)

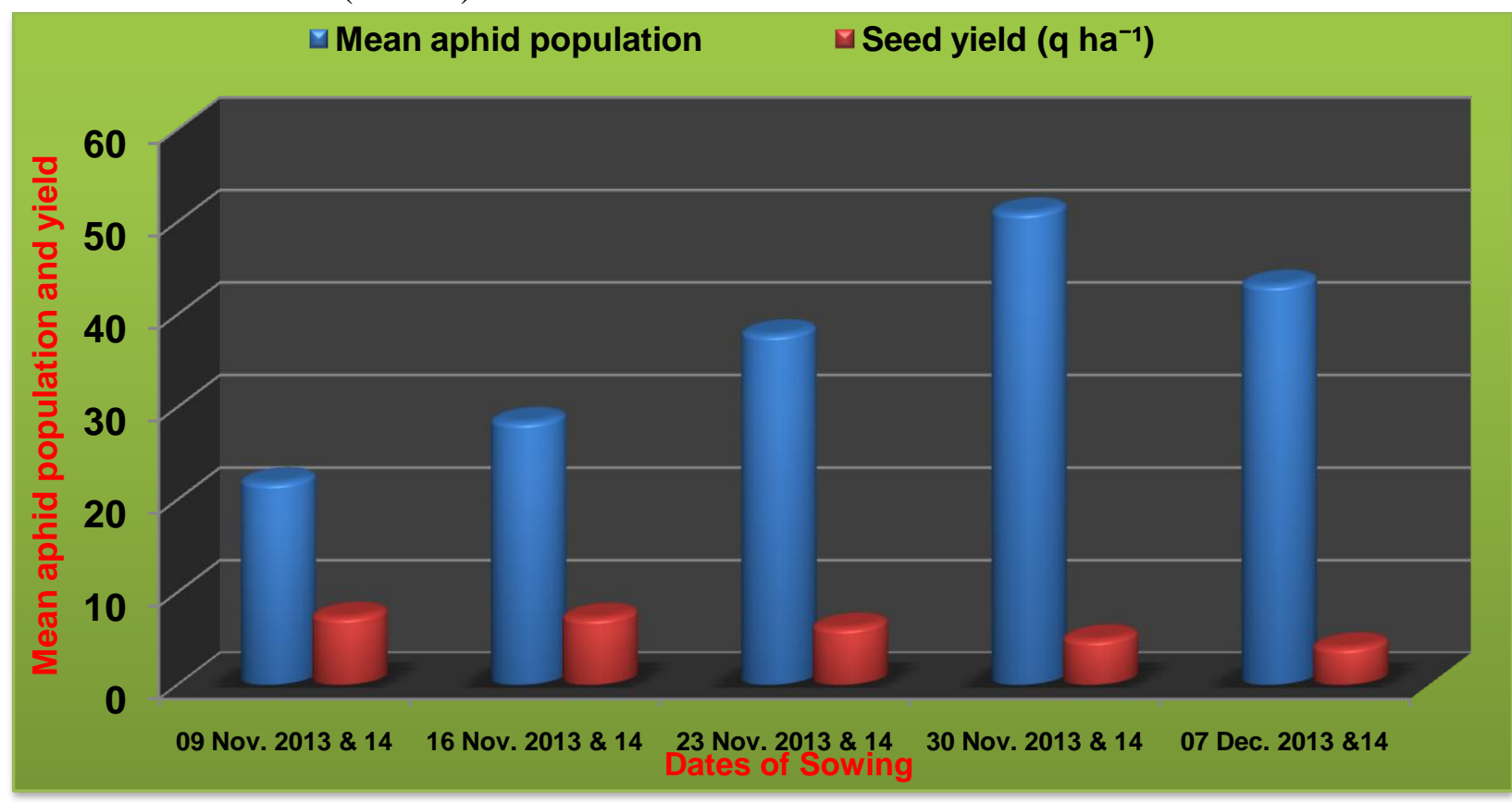

The present findings revealed that the it was maximum $\left(7.32 \mathrm{q} \mathrm{ha}^{-1}\right)$ followed by maximum yield, viz., 7.19 and $7.44 \quad \mathrm{q} \mathrm{ha}^{-1} \quad\left(7.21 \mathrm{q} \mathrm{ha}^{-1}\right)$ in early sown crop and minimum was observed is early sown crop $\left(9^{\text {th }} \quad\left(4.03 \mathrm{q} \mathrm{ha}^{-1}\right)\right.$ followed by $\left(4.88 \mathrm{q} \mathrm{ha}^{-1}\right)$ in late November) followed by 7.11 and $7.7 .30 \mathrm{q} \mathrm{ha}^{-1}$ (16 ${ }^{\text {th }}$ November) in rabi, 2013-14 and 201415 , respectively and these were at par to each other. However, minimum seed yield, viz., 3.99 and $4.08 \mathrm{q} \mathrm{ha}^{-1}$ followed by 4.85 and 4.91 $\mathrm{q} \mathrm{ha}{ }^{-1}$ was obtained in late sown crop $7^{\text {th }}$ December and $30^{\text {th }}$ November during both years and found both are at par to each other. sown crop (Table 1 \& Figure 1). Trehan et al. (1970), Singh (1979), Sharma (1990), Ram \& Pareek (1993), Marzouk \& Bawab (1999), Khinchi \& Kumawat (2014), Samadia \& Haldhar (2017) and Jat et al. (2016) observed low population of aphid, $R$. maidis and comparatively higher yield on early sown crop which corroborates with the present findings.

The pooled data of seed yield also showed that

Table 1. Effect of sowing dates on the incidence of Rhopalosiphum maidis of P. ovata during Rabi, 2013-14 and 2014-15 (Pooled)

\begin{tabular}{|c|c|c|c|c|c|c|c|c|c|c|c|c|c|c|}
\hline \multirow{3}{*}{$\begin{array}{l}\text { S. } \\
\text { No. }\end{array}$} & \multirow{3}{*}{$\begin{array}{l}\text { Sowing } \\
\text { dates }\end{array}$} & \multicolumn{12}{|c|}{ Mean aphid population per tiller } & \multirow{3}{*}{$\begin{array}{c}\text { Yield } \\
(\mathrm{q} \\
\left.\mathrm{ha}^{-1}\right)\end{array}$} \\
\hline & & \multicolumn{12}{|c|}{ Meteorological weeks of observations } & \\
\hline & & 2 & 3 & 4 & 5 & 6 & 7 & 8 & 9 & 10 & 11 & 12 & Mean & \\
\hline 1. & $\begin{array}{l}09^{\text {th }} \\
\text { Nov. }\end{array}$ & $\begin{array}{c}4.97 \\
(0.78)^{*}\end{array}$ & $\begin{array}{l}11.37 \\
(1.09)\end{array}$ & $\begin{array}{l}19.14 \\
(1.30)\end{array}$ & $\begin{array}{l}23.17 \\
(1.37)\end{array}$ & $\begin{array}{l}32.72 \\
(1.52)\end{array}$ & 39.60 & $50.12 * *$ & 33.83 & 14.20 & $(0.98)$ & $(0.51)$ & 21.84 & 7.32 \\
\hline
\end{tabular}




\begin{tabular}{|c|c|c|c|c|c|c|c|c|c|c|c|c|c|c|}
\hline 2. & $\begin{array}{l}16^{\text {th }} \\
\text { Nov. }\end{array}$ & $\begin{array}{c}2.46 \\
(0.54)\end{array}$ & $\begin{array}{c}8.06 \\
(0.96)\end{array}$ & $\begin{array}{l}13.20 \\
(1.15)\end{array}$ & $\begin{array}{l}32.31 \\
(1.52)\end{array}$ & $\begin{array}{l}44.83 \\
(1.66)\end{array}$ & $\begin{array}{l}51.67 \\
(1.72)\end{array}$ & $\begin{array}{l}70.17 \\
(1.85)\end{array}$ & $\begin{array}{l}49.90 \\
(1.71)\end{array}$ & $\begin{array}{l}21.71 \\
(1.36)\end{array}$ & $\begin{array}{l}13.23 \\
(1.16)\end{array}$ & $\begin{array}{c}4.64 \\
(0.74)\end{array}$ & $\begin{array}{l}28.38 \\
(1.47)\end{array}$ & 7.21 \\
\hline 3. & $\begin{array}{l}23^{\text {rd }} \\
\text { Nov. }\end{array}$ & $\begin{array}{c}1.22 \\
(0.35)\end{array}$ & $\begin{array}{c}5.88 \\
(0.84)\end{array}$ & $\begin{array}{r}9.82 \\
(1.03)\end{array}$ & $\begin{array}{l}40.28 \\
(1.62)\end{array}$ & $\begin{array}{l}60.38 \\
(1.79)\end{array}$ & $\begin{array}{l}70.94 \\
(1.86)\end{array}$ & $\begin{array}{l}92.14 \\
(1.97)\end{array}$ & $\begin{array}{l}69.92 \\
(1.85)\end{array}$ & $\begin{array}{l}37.48 \\
(1.59)\end{array}$ & $\begin{array}{l}18.17 \\
(1.28)\end{array}$ & $\begin{array}{l}10.08 \\
(1.04)\end{array}$ & $\begin{array}{l}37.85 \\
(1.59)\end{array}$ & 6.16 \\
\hline 4. & $\begin{array}{l}30^{\text {th }} \\
\text { Nov. }\end{array}$ & $\begin{array}{c}0.73 \\
(0.24)\end{array}$ & $\begin{array}{c}5.18 \\
(0.79)\end{array}$ & $\begin{array}{c}8.02 \\
(0.96)\end{array}$ & $\begin{array}{l}55.04 \\
(1.75)\end{array}$ & $\begin{array}{l}84.00 \\
(1.93)\end{array}$ & $\begin{array}{l}101.77 \\
(2.00)\end{array}$ & $\begin{array}{l}118.77 \\
(2.08)\end{array}$ & $\begin{array}{l}99.68 \\
(2.01)\end{array}$ & $\begin{array}{l}52.98 \\
(1.73)\end{array}$ & $\begin{array}{l}23.54 \\
(1.39)\end{array}$ & $\begin{array}{l}11.54 \\
(1.10)\end{array}$ & $\begin{array}{l}51.02 \\
(1.72)\end{array}$ & 4.88 \\
\hline 5. & $\begin{array}{l}07^{\text {th }} \\
\text { Dec. }\end{array}$ & $\begin{array}{c}0.34 \\
(0.13)\end{array}$ & $\begin{array}{c}4.32 \\
(0.73)\end{array}$ & $\begin{array}{c}6.95 \\
(0.90)\end{array}$ & $\begin{array}{l}45.88 \\
(1.67)\end{array}$ & $\begin{array}{l}72.24 \\
(1.86)\end{array}$ & $\begin{array}{l}84.69 \\
(1.93)\end{array}$ & $\begin{array}{l}101.89 \\
(2.01)\end{array}$ & $\begin{array}{l}83.74 \\
(1.93)\end{array}$ & $\begin{array}{l}43.95 \\
(1.65)\end{array}$ & $\begin{array}{l}20.27 \\
(1.33)\end{array}$ & $\begin{array}{l}11.07 \\
(1.08)\end{array}$ & $\begin{array}{l}43.21 \\
(1.65)\end{array}$ & 4.03 \\
\hline \multicolumn{2}{|c|}{$\mathrm{SEm} \pm$} & 0.02 & 0.02 & 0.03 & 0.03 & 0.03 & 0.03 & 0.03 & 0.03 & 0.03 & 0.02 & 0.02 & 0.03 & 0.55 \\
\hline \multicolumn{2}{|c|}{$\mathrm{CD}(5 \%)$} & 0.06 & 0.08 & 0.09 & 0.08 & 0.08 & 0.09 & 0.09 & 0.09 & 0.08 & 0.08 & 0.06 & 0.08 & 1.19 \\
\hline
\end{tabular}

* Figures in parenthesis are $\log (\mathrm{x}+1)$ values, ** Peak aphid population during crop seasons

The correlation coefficient ( $r$ ) of sowing dates with pooled data of population of aphids and yield also revealed similar trend, viz.; 0.891 and -0.976 , respectively. Thus, there was significant positive correlation between aphid population and sowing dates and significant negative correlation between aphid population and seed yield of blond psyllium during both the years. The regression equation of sowing dates on incidence of aphid showed the relationship between the dates of sowing as $\mathrm{X}$ and incidence as $\mathrm{Y}_{1}, \mathrm{Y}_{2}$ and $\mathrm{Y}_{3}$ during rabi, 2013-14 and 2014-15 and pooled, respectively. The variations explained by the equations were 79.2, 79.2 and 79.94 per cent during rabi, 2013-14, $2014-15$ and pooled of the total relations.

The ' $\mathrm{b}$ ' values for aphid populations and dates of sowing were $0.998,0.870$ and 0.934 for the year rabi, 2013-14, 2014-15 and pooled, respectively (Table 2). This indicates that the expected aphid population increased from 13.75 to 15.75 aphids per tiller during rabi, 2013-14, 14.33 to 16.07 aphids per tiller during rabi, 2014-15 and 14.04 to 15.91 aphid per tiller in pooled, with the delay in sowing of the crop by every week.

Table 2. Regression equation between dates of sowing and incidence of $R$. maidis and yield of $P$. ovata during rabi, 2013-14 and 2014-15 (Pooled)

\begin{tabular}{clccc}
\hline $\begin{array}{c}\text { S. } \\
\text { No }\end{array}$ & Particulars & $\begin{array}{l}\text { Correlation } \\
\text { coefficient }(\mathrm{r})\end{array}$ & $\begin{array}{c}\text { Regression equation } \\
\mathrm{Y}=\mathrm{a}+\mathrm{byx}\end{array}$ & $\begin{array}{l}\text { Coefficient } \\
\text { determination }\end{array}$ \\
\hline 1. & $\begin{array}{l}\text { Sowing dates v/s } \\
\text { Aphid incidence }\end{array}$ & 0.891 & $14.978+0.934 \mathrm{X}$ & 79.94 \\
2. & $\begin{array}{l}\text { Sowing dates v/s } \\
\text { grain yield }\end{array}$ & -0.976 & $8.848-0.127 \mathrm{X}$ & 95.27 \\
\hline
\end{tabular}

The regression equation of sowing dates and yield of blond psyllium showed the relationship between dates of sowing as $\mathrm{X}$ and yield $\left(\mathrm{q} \mathrm{ha}{ }^{-1}\right)$ incidence as $\mathrm{Y}_{4}, \mathrm{Y}_{5}$ and $\mathrm{Y}_{6}$ 
during Rabi, 2013-14, Rabi, 2014-15 and pooled, respectively. The variations explained by the equations were 94.9, 95.4 and 95.2, respectively. The equation showed the decreasing trend of the yield as sowing was delayed.

\section{References}

Bassett IJ \& Baum BR. 1969. Co-specificity of Plantagofastigiata of North America with $P$. ovata of the old world. Canadian Journal of Botany, 47: 1865-68.

Jat SM, Singh V, Kumar N \& Singh N. 2016. Effect of Sowing Dates on the Incidence of Rhopalosiphum maidis (Fitch) on Blond Psyllium, (Plantago Ovata) Forsk. The Ecosacan. Proceedings of National Conference on Harmony with Nature in Context of Resource Conservation and Climate Change October 22 - 24, 2016

Karnick CR. 1976. Studies on cultivation of Indian medicinal plant series. Indiandrugandphar maceutical sindustry,Nov.- Dec. pp. 41- 42.

Khinchi SK \& Kumawat KC. 2014. Effect of dates of sowing of blond psyllium, Plantago ovata on the incidence of aphid, Rhopalosiphum maidis. Journal of Insect Science, 27 (2): 246-249.

Marzouk IA \& Bawab AMO. 1999. Effect of sowing dates of barley on its infestation with corn leaf aphid ( $R$. maidis), Egyptian Journal of Agriculture Research, 77 (4): 1493-1499.
Ram N \& Pareek BL. 1993. Effect of date of sowing on the incidence of barley aphid, Rhopalosiphum maidis (Fith). Indian Journal of Entomology, 7: 69-71.

Robinson AG \& Hus SJ. 1963. Host plant record and biology of cereal grain and grasses in Manitoba (Homoptera; Aphididae) Canadian Entomologist, 95: 134-137.

Sagar P \& Jindla LN. 1984. An outbreak of aphid, Aphis gossypii Glover on Isabgol, Plantago ovata (L.) and its chemical control. Intl. Pest Control, 26(3): 76-77.

Samadia DK \& Haldhar SM. 2017. Breeding strategies and scope of improvement in arid zone fruit crop-plants under abiotic stressed agro-climate: an analysis. Journal of Agriculture and Ecology, 4: 1-13.

Singh VS. 1979. Effect of time of sowing on Incidence of corn leaf aphid, Rhopaiosi phummaidis (Fitch) on barley. First National Symposium on Barley, p. 69.

Trease GE \& Evans WC. 1978. Pharmacognsy 11th Edition Bailliere Tindail, a division of cassell and collies, Macmillan Publishers Ltd. London.

Trehan KBVK, Sharma RC \& Chandra RP. 1970. Note on Genetic stocks of barley (Hordeumvulgare L.) resistant to aphid, Rhopalosi phummaidis (Fitch.) Indian Journal of Agricultural Sciences, 40: 756-758. 